\title{
EFFICIENCY PERUBAHAN DESAIN LAYOUT PADA WEBSITE RESPONSIF SURAT KABAR DI INDONESIA TERHADAP PENGGUNA (Studi Kasus : Website Kompas, JPNN, dan Republika)
}

\author{
Auria F. Yogananti ${ }^{1}$, Noor Hasyim ${ }^{2}$, Ali Muqoddas ${ }^{3}$ \\ 1,2,3 Desain Komunikasi Visual, Fakultas IImu Komputer, Universitas Dian Nuswantoro \\ yogananti-au@hotmail.com ${ }^{1}$, hasyim.nahl@gmail.com ${ }^{2}$, ali.muqoddas@gmail.com ${ }^{3}$
}

\begin{abstract}
Abstrak
Perkembangan teknologi membuat website yang dahulu hanya dapat diakses melalui Personal Computer (PC) saat ini dapat diakses dari berbagai perangkat (devices) seperti tablet dan mobile phone. Sama halnya dengan website, surat kabar juga mengalami perkembangan, mulai dari surat kabar cetak, elektronik dan website (online). Website surat kabar yang dapat diakses melalui berbagai perangkat memiliki layout yang dapat berubah mengikuti luas monitor dari perangkat yang digunakan. Saat berinteraksi dengan website, pengguna bersentuhan langsung dengan antarmuka. Pengguna dapat menemui kesulitan dan kegunaan pada saat menggunakannya. Ketergunaan inilah yang sering disebut pula dengan usability. Dalam usability, efficiency merupakan salah satu komponen yang digunakan untuk mengukur kecepatan pengguna saat menjumpai sebuah konten, dalam hal ini adalah konten saat desain layout yang berubah akibat adanya perubahan perangkat. Pada penelitian ini, dilakukan Analisa ANOVA untuk mengetahui signifikansi efficiency pengguna saat mengakses website surat kabar dengan perangkat yang berbeda. Objek penelitian adalah website surat kabar nasional di Indonesia. Hasil yang didapatkan dari beberapa tahapan yang dilakukan untuk mengukur efficiency adalah pengguna membutuhkan waktu yang lama saat mengakses website surat kabar dalam perangkat yang berbeda sehingga perubahan layout pada perangkat yang berbeda secara signifikan mempengaruhi pengguna saat mengakses website surat kabar.
\end{abstract}

Kata Kunci: ANOVA, efficiency, layout, surat kabar, website responsif

\begin{abstract}
The development of technology makes website which only can be accessed through Personal Computer $(P C)$ currently can be accessed from various devices such as tablet and mobile phone. Same as the website, the newspaper also through developments, starting from printing newspaper, electronic newspaper, and website (online) newspaper. Online newspaper can be access through various devices and having layout which can be transformed to monitor area of devices. The change of layout on online newspapers causing website user interface design and content changed. Interacting with website, user directly contact with user interface. User also can found difficulties and convenience when used it. Those kinds of difficulties and conveniences called usability. In usability, efficiency was component used to measure user speed when encounter a content. Regarding this case was content when layout changed due the changed of devices. ANOVA analysis will be conducted to find the significance of user efficiency when accessing online newspaper on different devices. The object of this research is online newspaper of Indonesia national newspaper. The result obtained that user experienced a long time when accessed online website on different devices so that the change of layout on different devices significantly affected user when accessing online newspaper.
\end{abstract}

Keywords: ANOVA, efficiency, layout, online newspaper, responsive website 


\section{PENDAHULUAN}

Website dimulai pada tahun 1990 saat Berners-Lee dan Mike Sendall menemukan World Wide Web (Veen, 2001). Website terus mengalami perkembangan seiring dengan berkembangnya teknologi, dari website statis berubah menjadi dinamis dan dapat berubah menyesuaikan resolusi layar dari perangkat (devices) yang digunakan, atau yang sering disebut sebagai website responsif. Sama halnya dengan website statis, website responsif juga terdiri dari dua komponen pembentuk yaitu coding dan interface (antarmuka). Coding tidak dapat dilihat secara langsung oleh pengguna website namun interface dapat dilihat secara langsung oleh pengguna. Interface dalam sebuah website terdiri dari komponen desain yang memberikan keindahan pada sebuah website. Komponen-komponen desain terdiri dari beberapa unsur yang salah satunya adalah layout (Elliot \& Stocks, 2009). Layout dalam sebuah website membantu mengatur tata letak konten dan visual dalam sebuah website. Layout dalam sebuah website responsif bersifat elastis dan fleksibel (Marcotte, 2011), hal ini dikarenakan desain interface website harus dapat fit (sesuai) ke dalam monitor di sebuah perangkat.

Surat kabar, sama halnya dengan website, mengalami perubahan format karena adanya perkembangan teknologi. Dahulu surat kabar hanya dapat dibaca dalam format cetak namun saat ini dapat dibaca melalui digital format. Dalam bentuk digital surat kabar dapat dibaca melalui format elektronik ataupun online dalam bentuk website (Ihlström, 2005; Kiisa, 2015). Surat kabar cetak dan elektronik memiliki tampilan yang sama, namun formatnya berbeda karena surat kabar elektronik ada dalam bentuk file pdf. Berbeda dengan keduanya, website surat kabar tidak memiliki tampilan yang sama. Perbedaan tampilan antara surat kabar cetak dan elektronik dan website surat kabar dikarenakan adanya perbedaan layout pada keduanya. Layout surat kabar cetak dan elektronik terdiri dari header, body serta footer sedangkan website surat kabar tidak hanya memiliki header, body dan footer, karena seperti website pada umumnya, website memiliki navigasi dalam bentuk menu (Beaird, 2010). Menu-menu ini dapat berada di header, body dan footer.

Saat berinteraksi dengan surat kabar cetak, surat kabar elektronik serta website surat kabar, pengguna bersentuhan langsung dengan antarmuka yang terdapat didalamnya. Perbedaan dapat dirasakan pada saat pengguna berinteraksi dengan surat kabar cetak, surat kabar elektronik serta website surat kabar karena surat kabar cetak, surat kabar elektronik memiliki 2-Dimensi sedangkan website surat kabar memiliki N-Dimensi (Nielsen, 1999). Pada saat website surat kabar dibuka pada monitor yang dapat membawa pembaca menuju halaman berbeda yang tak terkira jumlahnya.

Sebuah website responsif surat kabar yang dapat diakses melalui berbagai perangkat yang memiliki perbedaan besar monitor. Perbedaan besar monitor menuntut website surat kabar dapat sesuai ke setiap monitor yang ada, hal tersebut tentu berdampak pada perubahan layout website. Perubahan layout menyebabkan desain antarmuka yang digunakan website akan berubah dan letak konten pun berubah. Perubahan letak konten pada website surat kabar dapat membawa pengguna menemui kesulitan ataupun kemudahan pada saat menggunakannya. Ketergunaan inilah yang sering 
disebut dengan usability (Rubin, J., \& Chisnell, 2008). Dalam usability, efficiency merupakan salah satu komponen yang digunakan untuk mengukur kecepatan pengguna saat menjumpai sebuah desain, sehingga perlu adanya penelitian untuk mengukur signifikasi efficiency pengguna saat pengguna menjumpai perubahan layout yang terjadi pada website responsif surat kabar. Adapun website surat kabar yang menjadi pusat penelitian adalah website surat kabar nasional di Indonesia yaitu Website Kompas, JPNN, dan Republika.

\subsection{Surat Kabar}

Setelah mesin cetak ditemukan oleh Johann Guternberg (Elvinaro, 2015) teknologi ini digunakan untuk berbagai kebutuhan termasuk salah satunya surat kabar. Surat kabar diperhitungkan mulai ada sekitar abad ke-17. Hingga saat ini surat kabar tetap ada dan berkembang mengikuti perubahan zaman. Surat kabar yang dahulunya berbentuk cetak berubah menjadi bentuk elektronik dan berubah lagi menjadi bentuk online yang dapat diakses melalui website surat kabar. Surat kabar cetak dan elektronik (dalam bentuk .pdf) tidak memiliki perbedaan layout namun lain halnya dengan website surat kabar, layout yang dimilikinya jauh berbeda, seperti pada gambar 1.
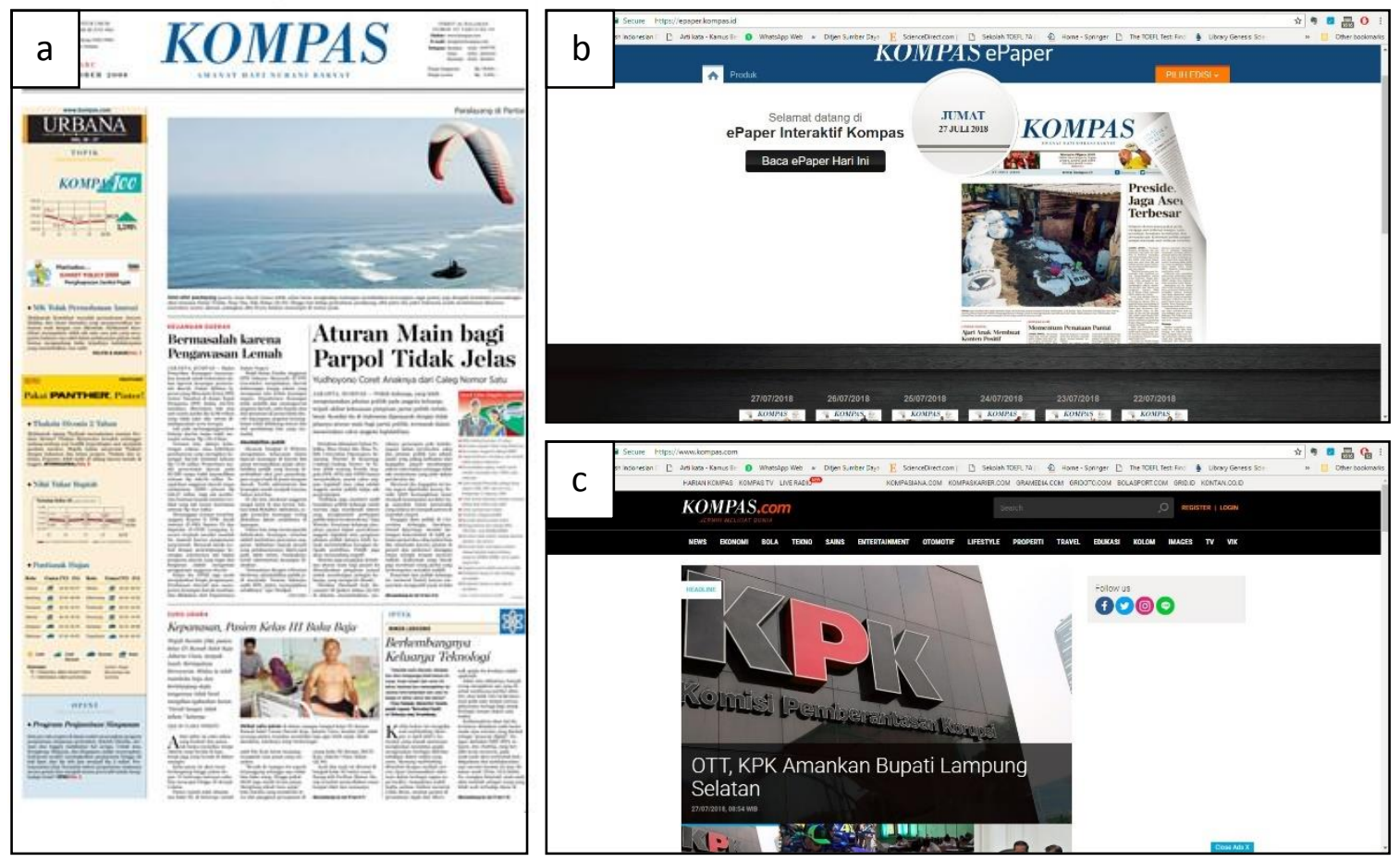

Gambar 1. Layout surat kabar Kompas; (a) versi cetak, (b) versi elektronik, dan (c) versi website [Sumber: https://febrianaherdianty.wordpress.com/2011/07/01/sirkulasi-surat-kabar-kompas/]

Surat kabar cetak merupakan printing desain, sedangkan website surat kabar merupakan merupakan digital desain. Printing desain dan digital desain memiliki perbedaan yang dapat dilihat dari beberapa hal sebagai berikut (Nielsen, 1999):

a) Dimensionally. Secara dimensi printing desain berbentuk dua dimensi. Pengguna yang bersentuhan langsung dapat membalik halaman dengan mudah. Lain halnya dengan digital desain yang berupa website, website memiliki $\mathrm{N}$ dimensi. $\mathrm{N}$ dimensi 
memungkinkan sebuah website memiliki halaman yang banyak dan bias tidak terkira jumlahnya walaupun yang dirasakan pengguna hanya 1 halaman saja.

b) Navigation. Pada printing desain, pengguna akan dengan mudah menemukan konten yang dicari karena dapat dengan mudah membalik halaman dan menemukan halaman yang dicari tanpa harus menekan atau menaikkan ke atas dan ke bawah. Pada website desain pengguna akan menemukan banyak navigasi seperti link dan tombol menu yang dapat mengarahkan pengguna ke halaman yang berbeda.

c) Response Time, Resolution, and Canvas Size. Printing desain akan memiliki waktu respon yang cepat karena pembaca dapat langsung melihat dan membaca konten yang ada di dalamnya. Website desain memiliki waktu respon yang berbeda, hal ini bergantung pada bandwidth yang digunakan. Selain itu keterbacaan sebuah website juga dipengaruhi dengan resolusi yang dimiliki monitor serta besar kecilnya monitor pada perangkat yang digunakan

d) Multimedia, Interactivity, and Overlays. Printing desain memiliki tingkat interaktifitas yang rendah karena tidak didukung oleh multimedia namun dalam website pengguna dapat lebih banyak berinteraksi. Pengguna dapat melihat gambar dengan kualitas yang bagus, video dan juga audio.

e) Respect (no, Relish) the Differences. Pengguna sat melihat printing desain akan secara selektif mencari informasi dengan mata namun pada web desain pengguna dapat pula menggunakan jari-jari tangan untuk menurunkan halaman ataupun menaikkan halaman web. Pengguna juga dapat mengklik link atau tombol menu dan berpindah ke halaman lain dengan mudah.

\subsection{Website Responsif}

Perbedaan besar monitor pada perangkat yang berbeda menjadi salah satu alasan website responsif muncul. Website responsif dapat diakses melalui monitor PC, monitor tablet ataupun monitor mobile phone dengan baik tanpa banyak kendala karena website dapat menyesuaikan dalam monitor-monitor tersebut. Website responsif terdiri dari tiga komponen penting yang menjadi inti (Marcotte, 2011). Adapun ke-3 komponen inti tersebut adalah:

a. Grid yang fleksibel

Website memiliki desain yang didasari oleh grid yang membentuk kolom-kolom. Grid dalam website responsif memiliki nilai yang fleksibel sehingga lebar dari sebuah website responsif dapat berubah mengikuti lebar monitor.

b. Gambar dan Media yang fleksibel

Gambar dan Media yang berada dalam sebuah website responsif juga harus dapat menyesuaikan diri dengan luas layar. Biasanya untuk menghindari waktu respon yang lama, gambar dan media yang ada, besaran file akan diperkecil. Namun efek samping dari adanya hal tersebut adalah menurunnya kualitas gambar dan media yang ada.

c. Query Media

Query media memungkinkan browser yang dipakai website untuk berubah dengan mudah sesuai dengan style yang digunakan. Fungsi seperti hal tersebut dinamakan breakpoint. 


\subsection{Usability}

Saat Pengguna berinteraksi dengan komputer, ada banyak hal yang dapat ditemukan oleh pengguna. Pengguna dapat menemukan kemudahan, pengguna juga dapat menemukan kesulitan saat menggunakannya. Ketergunaan inilah yang dapat disebut usability. Pada tahun 1979 Bennet mulai mengenalkan usability yang merupakan keefektifitasan dari kerja manusia. Di tahun 1991 Shackel memberikan penjelasan yang berbeda mengenai usability dengan menjelaskan bahwasanya usability adalah kemampuan yang dipakai pengguna saat menggunakan sesuatu dengan mudah dan efektif (Galitz, 2007).

Usability pada website dapat dipenuhi oleh tiga kriteria (Mvungi, Joel ; Tossy, 2015), adapun kriteria tersebut adalah:

a) Content Visibility. Hal ini berkaitan dengan kemudahan dalam pemahaman terhadap struktur informasi yang ditawarkan oleh website.

b) Ease Of Content Access. Kemudahan dalam mengakses konten yang ada didalam website

c) Ease of Content Browsing. Setiap konten yang ada didalam website harus dapat dengan mudah diidentifikasi oleh pengguna.

Dalam bukunya Jeff Rubin juga mengatakan bahwa terdapat beberapa unsur yang menjadi unsur usability. Unsur-unsur tersebut adalah kegunaan, efisiensi, efektivitas, kepuasan dan aksesibilitas merupakan unsur-unsur dalam usability (Rubin, J., \& Chisnell, 2008) selain itu usability juga dapat ditentukan dengan 5 komponen (Nielsen, 2012), yaitu Learnability, Efficiency, Memorability, Errors, dan Satisfaction dengan melakukan beberapa tugas yang berkaitan dengan desain terkait.

a. Learnability adalah komponen digunakan untuk mengukur kemudahan saat pengguna menyelesaikan tugas yang diberikan.

b. Efficiency adalah komponen yang digunakan untuk mengukur kecepatan waktu yang dipakai pleh pengguna saat menyelesaikan tugas.

c. Memorability adalah komponen digunakan untuk mengukur kemudahan pengguna saat mengerjakan kembali tugas yang diberikan.

d. Errors adalah komponen yang digunakan untuk mengukur kesalahan pengguna saat diberikan tugas.

e. Satisfaction adalah komponen yang digunakan untuk mengukur tingkat kepuasan pengguna setelah menyelesaikan sebuah tugas.

\section{METODE PENELITIAN}

\subsection{Partisipan}

Dalam penelitian terdapat 115 orang peserta yang ikut berpartisipasi. Semua peserta yang berpartisipasi merupakan mahasiswa Universitas Dian Nuswantoro yang sedang menjalani mata kuliah desain web. Peserta rata-rata berusia 20-22 tahun. Semua peserta yang berpartisipasi mengetahui dengan jelas pengoperasian PC, tablet ataupun mobile phone dan dapat mengakses website melalui perangkat tersebut. 


\subsection{Prosedur}

Adapun prosedur yang dilakukan dalam pelaksanaan survei adalah sebagai berikut :

1) Peserta diminta untuk membuka tiga website surat kabar nasional di Indonesia.

Website surat kabar yang digunakan pada penelitian ini adalah surat kabar Kompas dengan link website surat kabar https://www.kompas.com/, surat kabar Jawa Pos dengan link website surat kabar https://www.jpnn.com/, dan yang terakhir adalah surat kabar Republika dengan link website https://www.republika.co.id/.

2) Setiap peserta diberikan empat tugas yang berisi perintah untuk mencari headline, menemukan berita favorit, berita-berita lain dan menu ekonomi. Semua tugas dikerjakan melalui tiga perangkat yaitu $\mathrm{PC}$, tablet dan mobile phone yang memiliki lebar monitor yang berbeda.

3) Setelah tugas dikerjakan peserta diminta mengisi kuisioner yang berisi 12 pertanyaan mengenai efficiency yang merupakan komponen dari usability. Jadi penelitian ini hanya fokus pada tingkat kecepatan waktu yang dipakai oleh pengguna saat menyelesaikan tugas.

\subsection{Pengukuran Hasil}

Setelah semua peserta menyelesaikan semua tugas yang diberikan, semua hasil diolah menggunakan microsoft excel 2013 dan dihitung menggunakan metode analisa ANOVA untuk mengetahui seberapa signifikan perubahan layout yang terjadi pada website surat kabar yang dibuka dalam perangkat yang memiliki layar yang berbeda.

\section{HASIL DAN PEMBAHASAN}

\subsection{Hasil}

Setelah dilakukan pengolahan data menggunakan microsoft excel 2013 terhadap dari kuisioner yang disebarkan kepada 115 responden mengenai lama waktu yang diperlukan untuk menemukan judul headline, berita-berita lainnya, dan menu ekonomi dalam perangkat yang berbeda (monitor PC, tablet, dan mobile phone) adalah sebagai berikut:

\section{a. Website Kompas}

1. Nilai sebaran nilai rata-rata untuk waktu yang digunakan dalam menemukan judul headline pada PC, tablet, dan mobile phone adalah 8.56 untuk monitor PC, 7.81 untuk tablet dan 7.31 untuk mobile phone dengan sebaran jumlah data atau standar deviasi sebesar 1.53 untuk monitor PC, 1.58 untuk tablet dan 1.93 untuk mobile phone, seperti yang terlihat pada gambar 2 . 


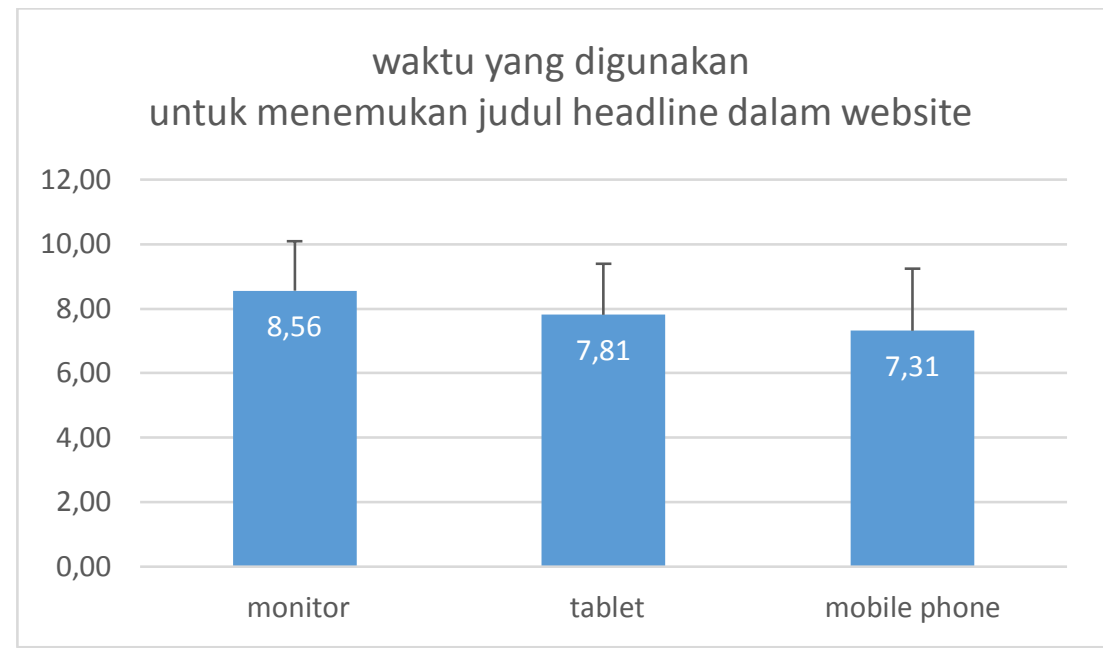

Gambar 2. Sebaran nilai rata-rata dan standar deviasi waktu yang digunakan untuk menemukan judul headline dalam website Kompas

[Sumber: Dokumentasi Penulis]

Data tersebut menunjukkan bahwa pengguna lebih cepat menemukan judul headline dalam PC monitor dibandingkan dengan tablet dan mobile phone. Adapun nilai signifikansi dapat dilihat sebagai berikut:

\begin{tabular}{|c|c|c|c|c|c|}
\hline \multicolumn{6}{|c|}{ Anova: Single Factor [1] } \\
\hline \multicolumn{6}{|l|}{ SUMMARY } \\
\hline Groups & Count & Sum & Average & Variance & \\
\hline monitor & 115 & 984 & 8.556522 & 2.371777 & \\
\hline tablet & 115 & 898 & 7.808696 & 2.524485 & \\
\hline mobile phone & 115 & 841 & 7.313043 & 3.743249 & \\
\hline \multicolumn{6}{|l|}{ ANOVA } \\
\hline Source of Variation & $S S$ & $\overline{d f}$ & $\overline{M S}$ & $F$ & $P$-value \\
\hline Between Groups & 90.12754 & 2 & 45.06377 & 15.64803 & 3.14292E-07 3.022127 \\
\hline Within Groups & 984.9043 & 342 & 2.879837 & & \\
\hline Total & 1075.032 & 344 & & & \\
\hline
\end{tabular}

Gambar 3. Nilai ANOVA untuk waktu yang digunakan saat menemukan judul headline dalam website Kompas pada perangkat yang berbeda (monitor PC, tablet, dan mobile phone)

[Sumber: Dokumentasi Penulis]

Gambar 3 menunjukan bahwa analisa signifikasi untuk monitor PC, tablet, dan mobile phone adalah signifikan karena nilai P-Value sebesar $(3,14 \mathrm{E}-07)$ dan $\mathrm{F}$ Hitung $(15,65)$ lebih besar dari F Critical.

2. Nilai sebaran nilai rata-rata untuk waktu yang digunakan dalam menemukan judul berita yang lain pada monitor $\mathrm{PC}=8.31$, tablet $=7.36$ dan mobile phone $=6.97$. Sebaran jumlah data atau standar deviasi sebesar 1.62 untuk monitor, 1.71 untuk tablet dan 1.97 untuk mobile phone, seperti yang terlihat pada gambar 4 . 


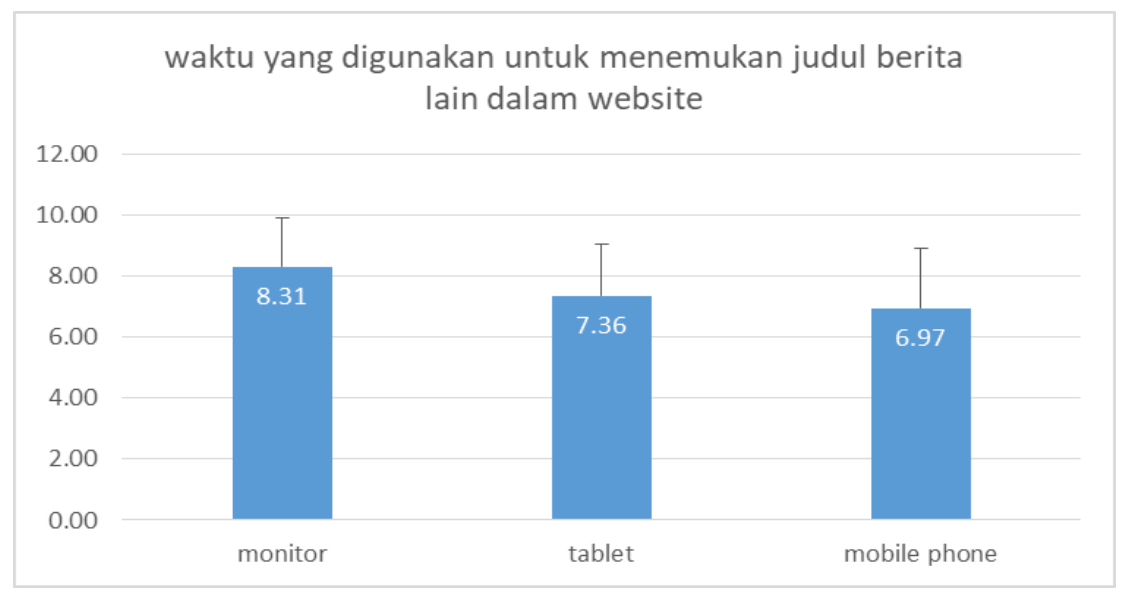

Gambar 4. Sebaran nilai rata-rata dan standar deviasi waktu yang digunakan untuk menemukan judul berita lain dalam website Kompas

[Sumber: Dokumentasi Penulis]

Data tersebut menunjukkan bahwa pengguna juga lebih cepat menemukan judul berita lain saat menggunakan monitor PC dibandingkan dengan penggunaan tablet dan mobile phone. Adapun nilai signifikansi dapat dilihat sebagai berikut:

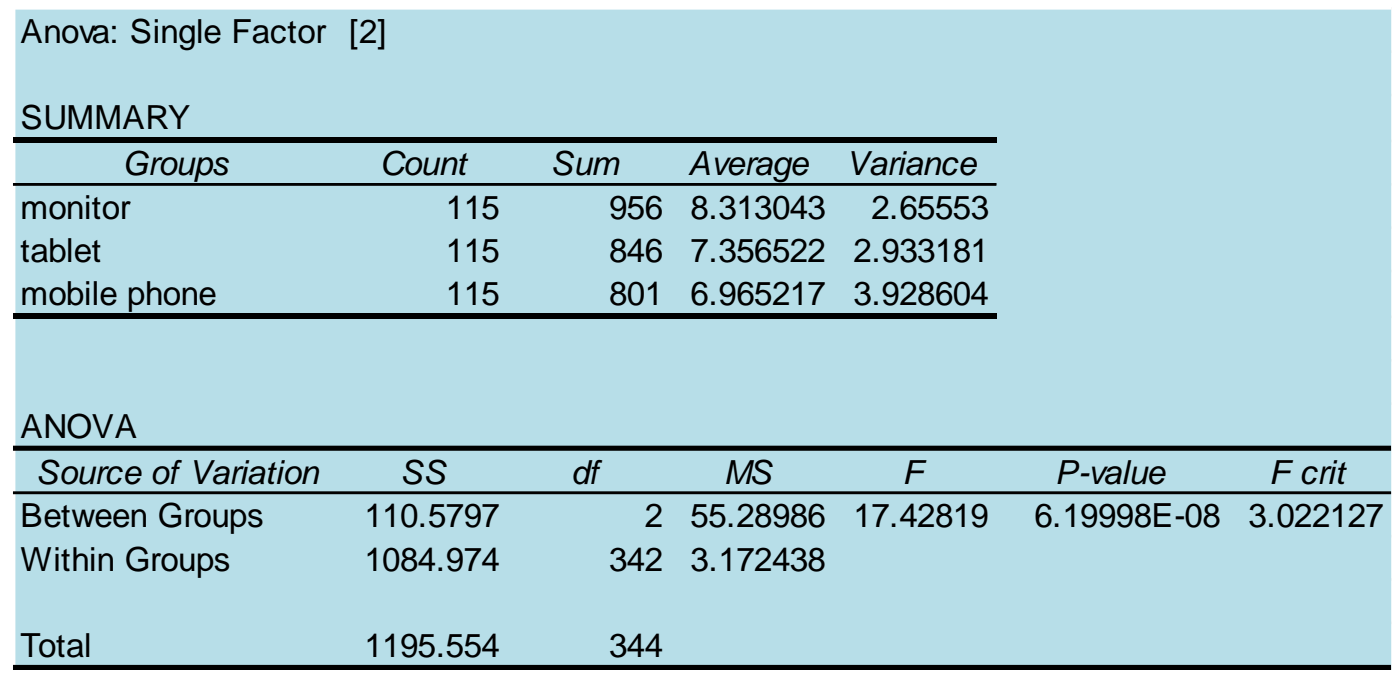

Gambar 5. Nilai ANOVA untuk waktu yang digunakan saat menemukan judul berita lain dalam website Kompas pada perangkat yang berbeda (monitor PC, tablet dan mobile phone)

[Sumber: Dokumentasi Penulis]

Gambar 5 menunjukan bahwa analisa signifikasi untuk monitor PC, tablet dan mobile phone adalah signifikan, hal ini terjadi karena nilai P-Value sebesar $(6,19 \mathrm{E}-$ 08) dan F Hitung $(17,42)$ lebih besar dari F Critical.

3. Nilai sebaran nilai rata-rata untuk waktu yang digunakan dalam menemukan menu ekonomi pada monitor PC, tablet dan mobile phone adalah 8.47 untuk monitor, 7.68 untuk tablet dan 7.20 untuk mobile phone dengan sebaran jumlah data atau standar deviasi sebesar 1.63 untuk monitor, 1.45 untuk tablet dan 1.75 untuk mobile phone, seperti yang terlihat pada gambar 6 . 


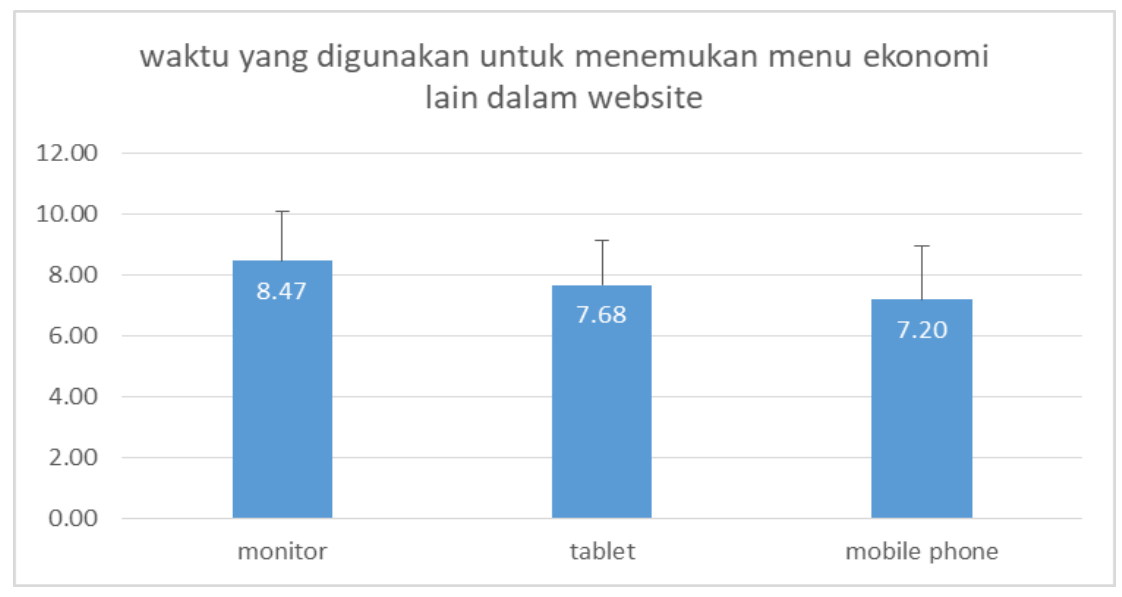

Gambar 6. Sebaran nilai rata-rata dan standar deviasi waktu yang digunakan untuk menemukan menu ekonomi dalam website Kompas

[Sumber: Dokumentasi Penulis]

Data tersebut menunjukkan bahwaa pengguna lebih cepat menemukan menu ekonomi dalam monitor PC dibandingkan pada saat menggunakan tablet dan mobile phone. Adapun nilai signifikansi dapat dilihat sebagai berikut:

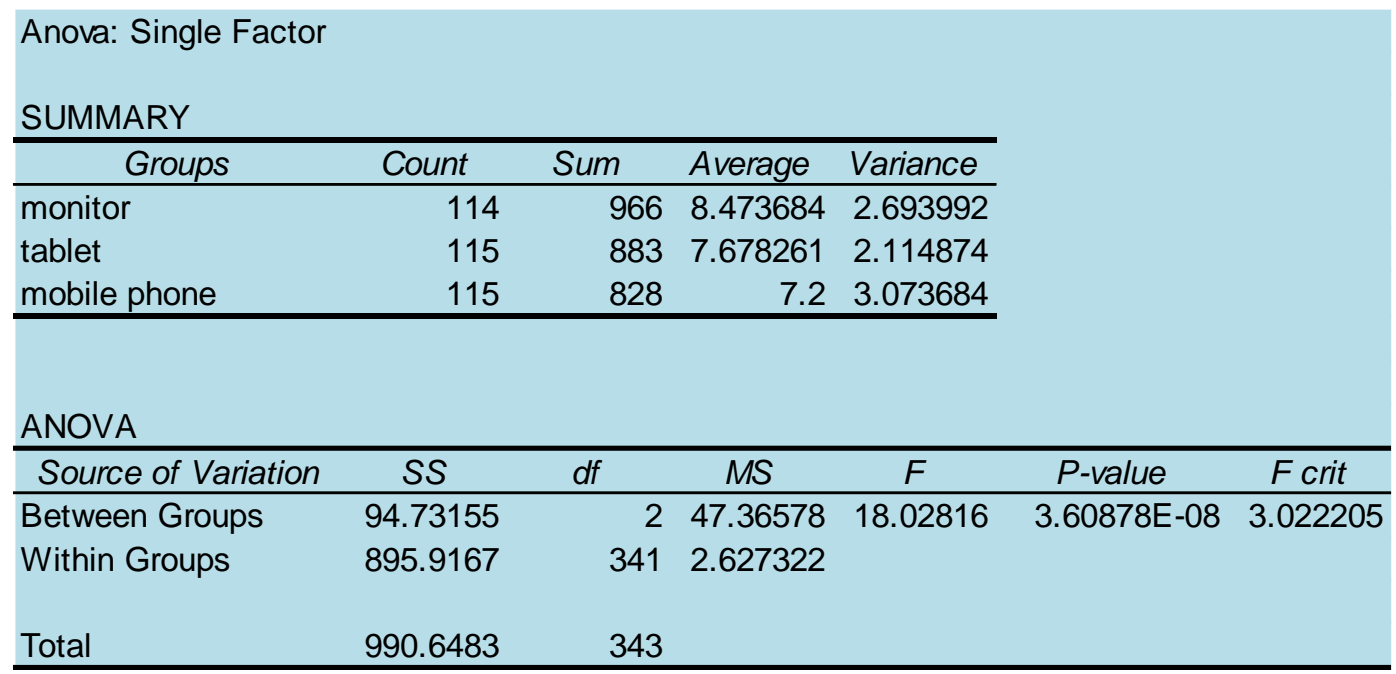

Gambar 7. Nilai ANOVA untuk waktu yang digunakan saat menemukan menu ekonomi dalam website Kompas pada perangkat yang berbeda (monitor PC, tablet dan mobile phone)

[Sumber: Dokumentasi Penulis]

Gambar 7 menunjukan bahwa analisa signifikasi untuk monitor PC, tablet dan mobile phone adalah signifikan karena nilai P-Value sebesar $(3,6 \mathrm{E}-07)$ dan F Hitung $(18,02)$ lebih besar dari F Critical.

\section{b. Website JPNN}

1. Nilai sebaran nilai rata-rata untuk waktu yang digunakan dalam menemukan judul headline pada monitor PC, tablet dan mobile phone adalah 8.44 untuk monitor, 7.97 untuk tablet dan 7.62 untuk mobile phone dengan sebaran jumlah data atau 
standar deviasi sebesar 1.67 untuk monitor, 1.58 untuk tablet dan 1.74 untuk mobile phone, seperti yang terlihat pada gambar 8 .

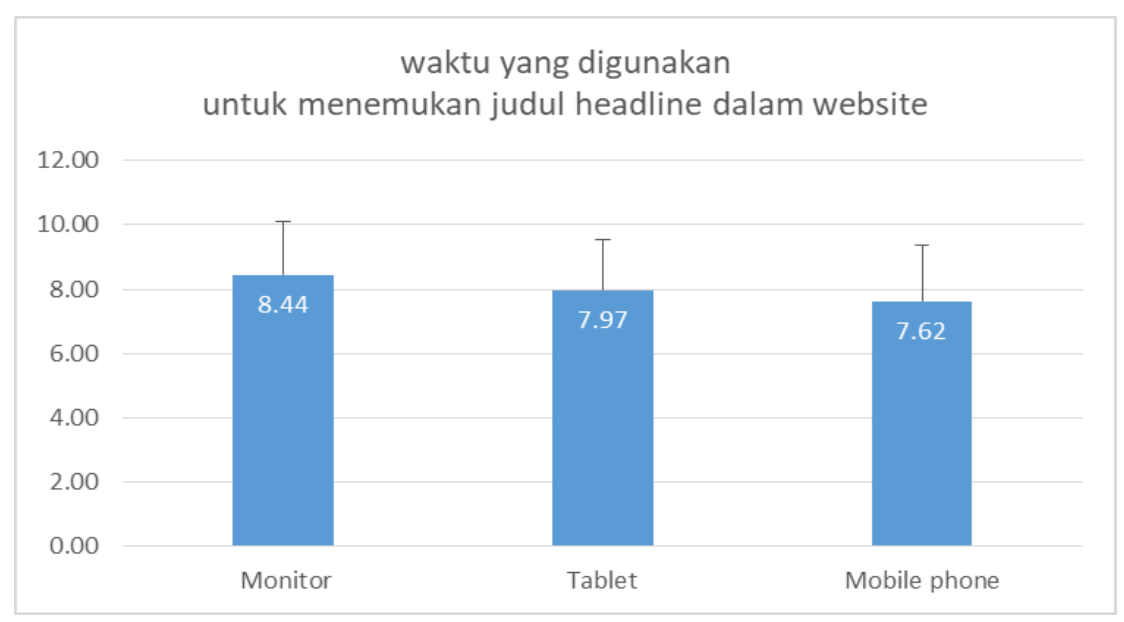

Gambar 8. Sebaran nilai rata-rata dan standar deviasi waktu yang digunakan untuk menemukan judul headline dalam website JPNN [Sumber: Dokumentasi Penulis]

Data tersebut menunjukkan bahwa pengguna lebih cepat menemukan menu ekonomi dalam monitor PC dibandingkan dengan tablet dan mobile phone. Adapun nilai signifikansi dapat dilihat sebagai berikut:

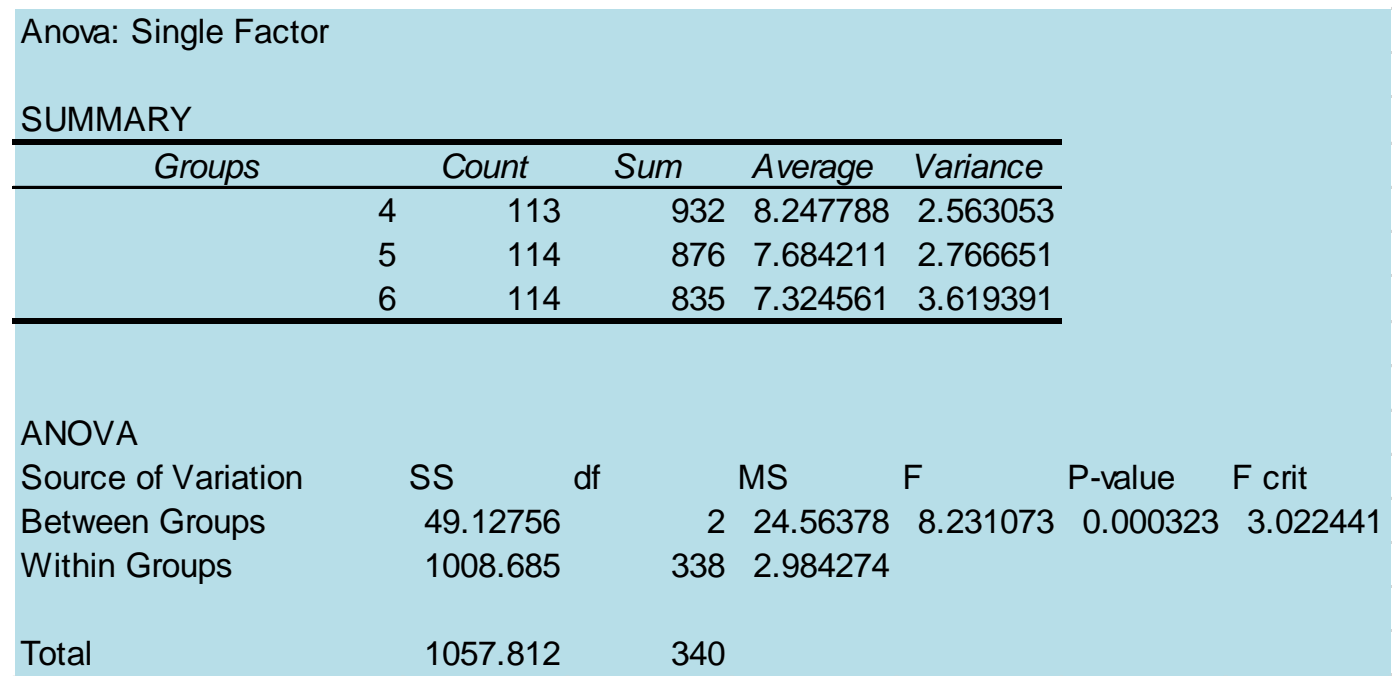

Gambar 9. Nilai ANOVA untuk waktu yang digunakan saat menemukan judul headline dalam website JPNN pada perangkat yang berbeda (monitor PC, tablet dan mobile phone)

[Sumber: Dokumentasi Penulis]

Gambar 9 menunjukan bahwa analisa signifikasi untuk monitor PC, tablet dan mobile phone adalah signifikan karena nilai P-Value sebesar (0.0003) dan F Hitung $(8,23)$ lebih besar dari F Critical. 
2. Nilai sebaran nilai rata-rata untuk waktu yang digunakan dalam menemukan Judul berita yang lain pada monitor $P C=8.21$, tablet $=7.66$ dan mobile phone $=7.31$. Sebaran jumlah data atau standar deviasi sebesar 1.64 untuk monitor, 1.67 untuk tablet dan 1.89 untuk mobile phone, seperti yang terlihat pada gambar 10 .

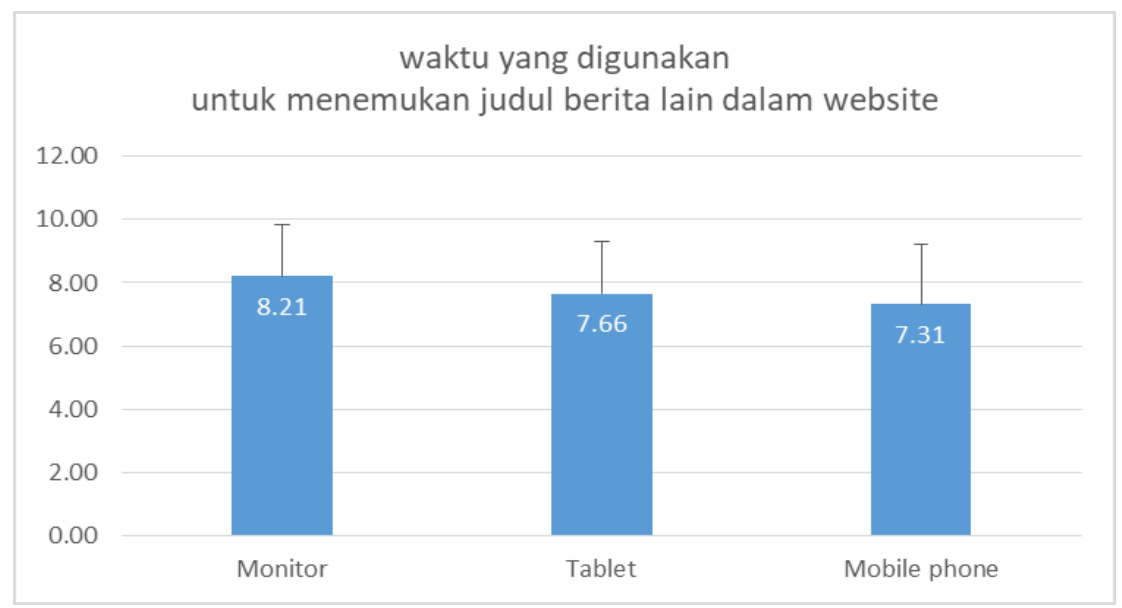

Gambar 10. Sebaran nilai rata-rata dan standar deviasi waktu yang digunakan untuk menemukan judul berita lain dalam website JPNN

[Sumber: Dokumentasi Penulis]

Data tersebut menunjukkan bahwa pengguna juga lebih cepat menemukan judul berita lain saat menggunakan monitor PC dibandingkan dengan penggunaan tablet dan mobile phone. Adapun nilai signifikansi dapat dilihat sebagai berikut:

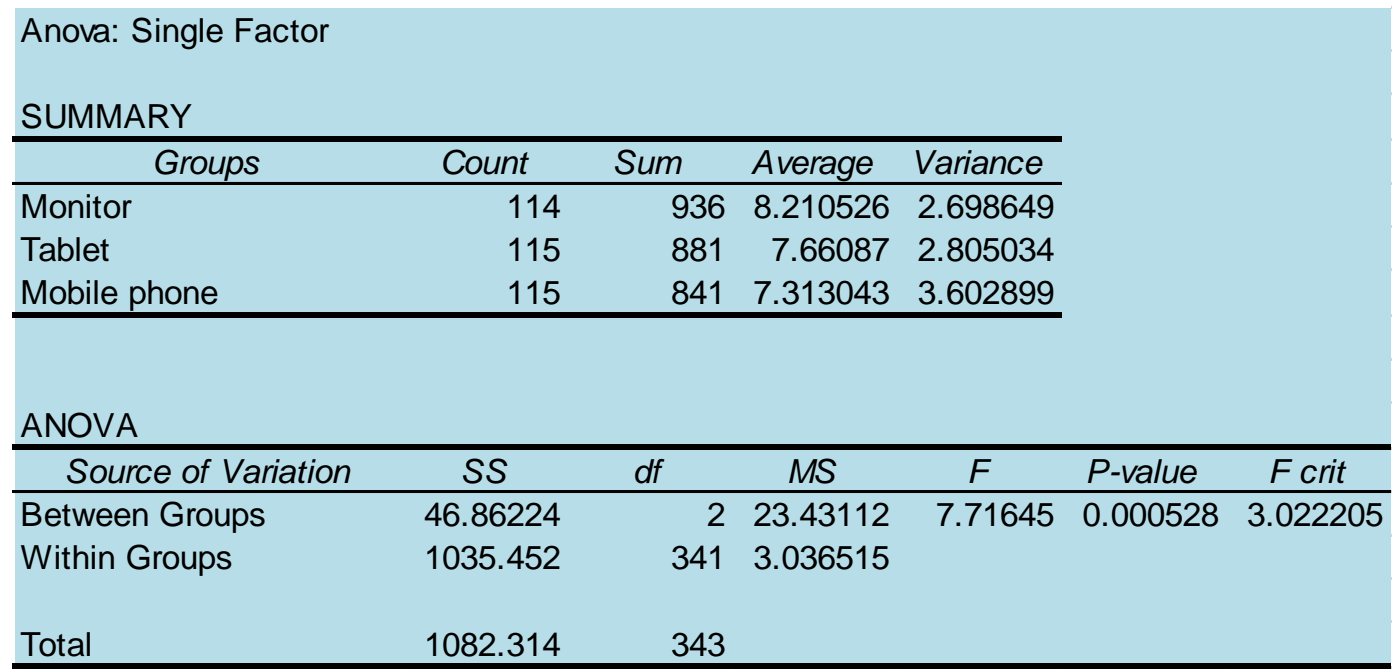

Gambar 11. Nilai ANOVA untuk waktu yang digunakan saat menemukan judul berita lain dalam website JPNN pada perangkat yang berbeda (monitor PC, tablet dan mobile phone)

[Sumber: Dokumentasi Penulis]

Gambar 11 menunjukan bahwa analisa signifikasi untuk monitor PC, tablet dan mobile phone adalah signifikan, hal ini terjadi karena nilai P-Value sebesar (0.0005) dan F Hitung (7.71) lebih besar dari F Critical. 
3. Nilai sebaran nilai rata-rata untuk waktu yang digunakan dalam menemukan menu ekonomi pada monitor PC, tablet dan mobile phone adalah 8.45 untuk monitor, 7.85 untuk tablet dan 7.54 untuk mobile phone dengan sebaran jumlah data atau standar deviasi sebesar 1.61 untuk monitor, 1.60 untuk tablet dan 1.85 untuk mobile phone, seperti yang terlihat pada gambar 12 .

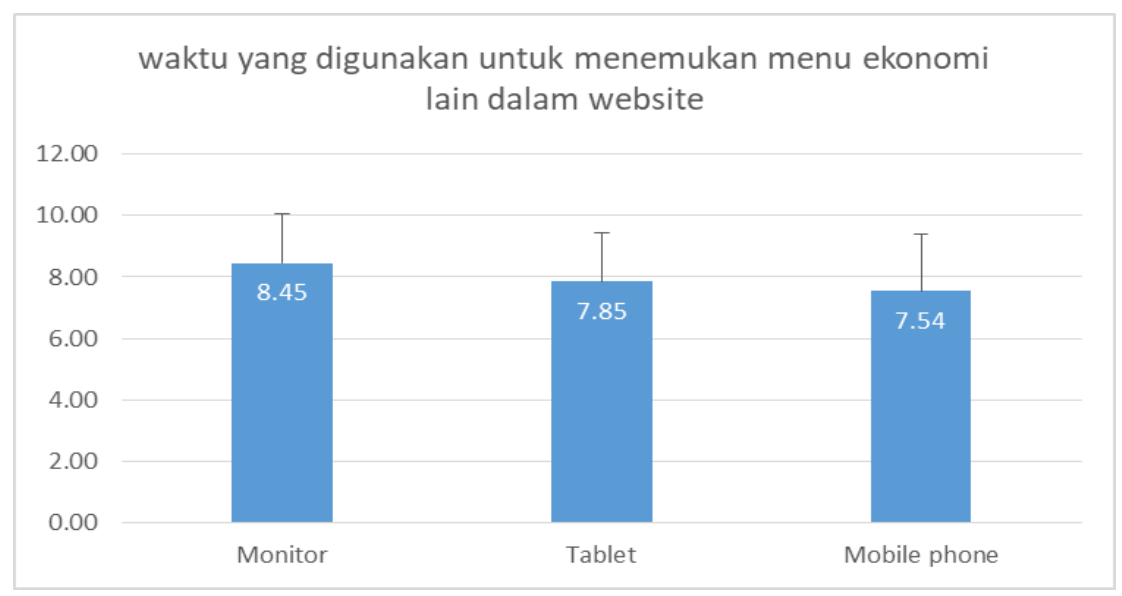

Gambar 12. Sebaran nilai rata-rata dan standar deviasi waktu yang digunakan untuk menemukan menu ekonomi dalam website JPNN

[Sumber: Dokumentasi Penulis]

Data tersebut menunjukkan bahwa pengguna lebih cepat menemukan menu ekonomi dalam monitor PC dibandingkan dengan tablet dan mobile phone. Adapun nilai signifikansi dapat dilihat sebagai berikut:

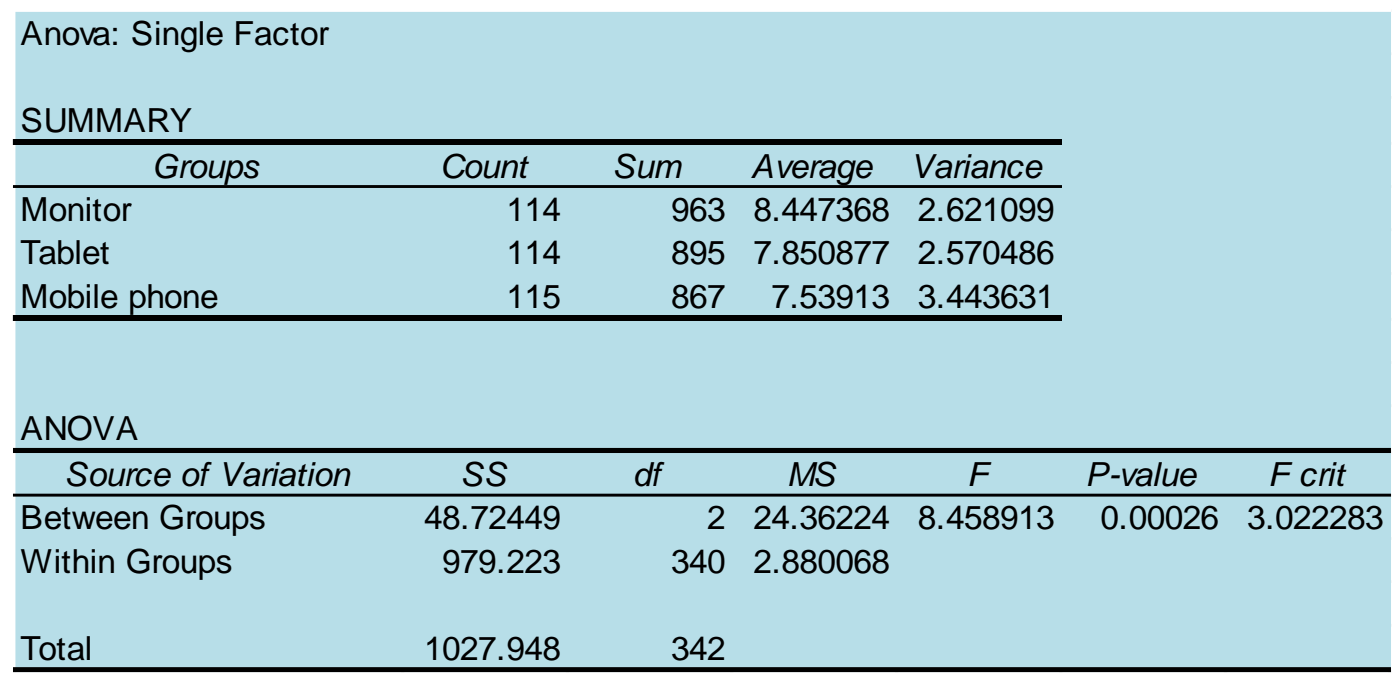

Gambar 13. Nilai ANOVA untuk waktu yang digunakan saat menemukan menu ekonomi dalam website JPNN pada perangkat yang berbeda (monitor PC, tablet dan mobile phone)

[Sumber: Dokumentasi Penulis]

Gambar 13 menunjukan bahwa analisa signifikasi untuk monitor PC, tablet dan mobile phone adalah signifikan karena nilai P-Value sebesar (0.00026) dan F Hitung (8.45) lebih besar dari F Critical. 


\section{c. Website Republika}

1. Nilai sebaran nilai rata-rata untuk waktu yang digunakan dalam menemukan judul headline pada monitor PC, tablet dan mobile phone adalah 8.38 untuk monitor, 8.03 untuk tablet dan 7.54 untuk mobile phone dengan sebaran jumlah data atau standar deviasi sebesar 1.64 untuk monitor, 1.42 untuk tablet dan 1.67 untuk mobile phone, seperti yang terlihat pada gambar 14 .

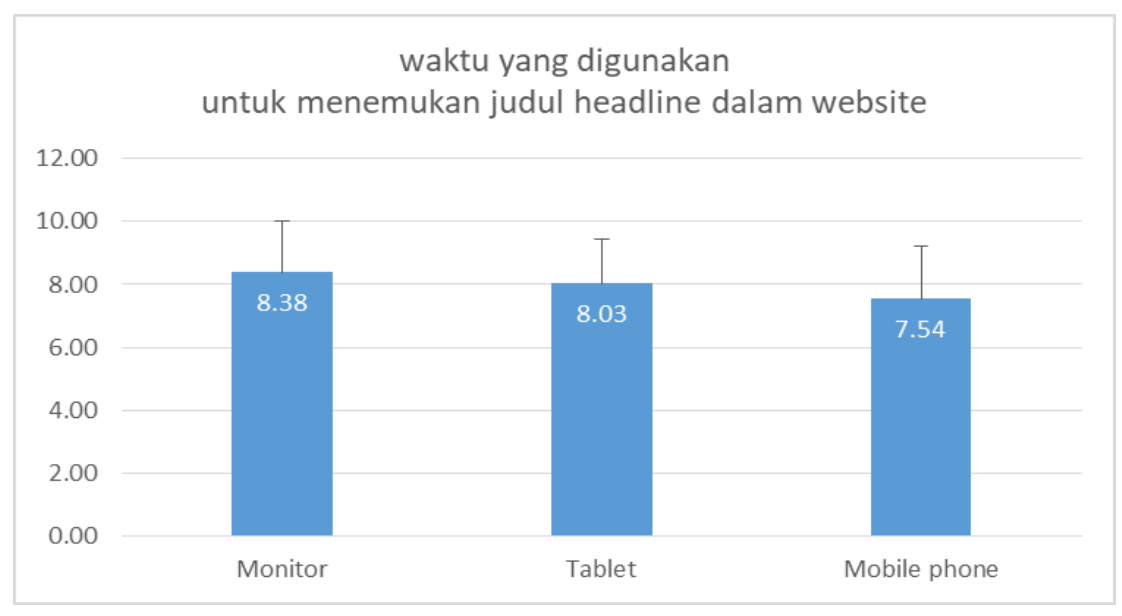

Gambar 14. Sebaran nilai rata-rata dan standar deviasi waktu yang digunakan untuk menemukan judul headline dalam website Republika

[Sumber: Dokumentasi Penulis]

Data tersebut menunjukkan bahwa pengguna lebih cepat menemukan judul headline dalam Monitor PC dibandingkan dengan tablet dan mobile phone. Adapun nilai signifikansi dapat dilihat sebagai berikut:

Anova: Single Factor

\begin{tabular}{lrrrr}
\multicolumn{1}{l}{ SUMMARY } \\
\multicolumn{1}{c}{ Groups } & Count & \multicolumn{1}{c}{ Sum } & Average & Variance \\
\hline Monitor & 115 & 964 & 8.382609 & 2.711976 \\
Tablet & 115 & 923 & 8.026087 & 2.043173 \\
Mobile phone & 114 & 860 & 7.54386 & 2.798944 \\
\hline
\end{tabular}

\begin{tabular}{|c|c|c|c|c|c|c|}
\hline Source of Variation & SS & $d f$ & $M S$ & $F$ & $P$-value & $F_{\text {crit }}$ \\
\hline Between Groups & 40.55967 & 2 & 20.27983 & 8.056482 & 0.000381 & 3.022205 \\
\hline Within Groups & 858.3677 & 341 & 2.517207 & & & \\
\hline Total & 898.9273 & 343 & & & & \\
\hline
\end{tabular}

Gambar 15. Nilai ANOVA untuk waktu yang digunakan saat menemukan judul headline dalam website Republika pada perangkat yang berbeda (monitor PC, tablet dan mobile phone)

[Sumber: Dokumentasi Penulis]

Gambar 15 menunjukan bahwa analisa signifikasi untuk Monitor PC, tablet dan mobile phone adalah signifikan karena nilai P-Value sebesar (0.000381) dan F Hitung $(8,05)$ lebih besar dari F Critical. 
2. Nilai sebaran nilai rata-rata untuk waktu yang digunakan dalam menemukan judul berita yang lain pada monitor $P C=8.37$, tablet $=7.77$ dan mobile phone $=7.43$. Sebaran jumlah data atau standar deviasi sebesar 1.44 untuk monitor, 1.50 untuk tablet dan 1.82 untuk mobile phone, seperti yang terlihat pada gambar 16 .

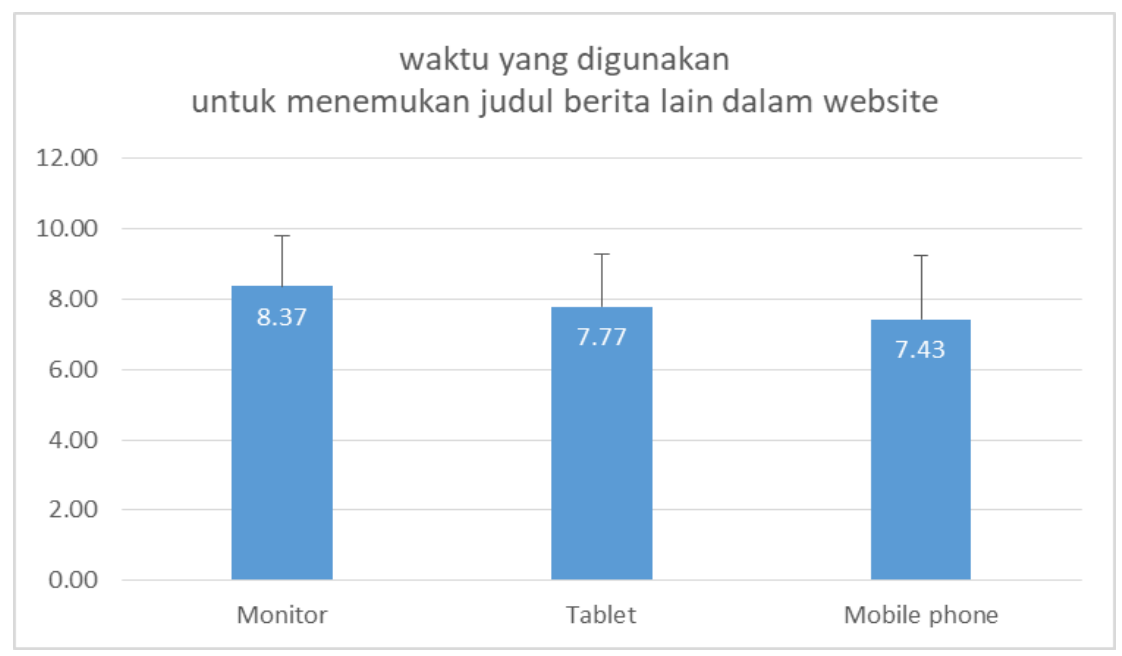

Gambar 16. Sebaran nilai rata-rata dan standar deviasi waktu yang digunakan untuk menemukan judul berita lain dalam website Republika [Sumber: Dokumentasi Penulis]

Data tersebut menunjukkan bahwa pengguna juga lebih cepat menemukan judul berita lain saat menggunakan monitor PC dibandingkan dengan penggunaan tablet dan mobile phone. Adapun nilai signifikansi dapat dilihat sebagai berikut:

Anova: Single Factor

SUMMARY

\begin{tabular}{lrrll}
\hline \multicolumn{1}{c}{ Groups } & Count & \multicolumn{1}{c}{ Sum } & Average & Variance \\
\hline Monitor & 113 & 946 & 8.371681 & 2.092762 \\
Tablet & 115 & 894 & 7.773913 & 2.264226 \\
Mobile phone & 114 & 847 & 7.429825 & 3.344589 \\
\hline
\end{tabular}

\begin{tabular}{|c|c|c|c|c|c|c|}
\hline Source of Variation & $S S$ & $d f$ & $M S$ & $F$ & $P$-value & $F$ crit \\
\hline Between Groups & 51.52982 & 2 & 25.76491 & 10.03424 & 5.84E-05 & 3.022362 \\
\hline Within Groups & 870.4497 & 339 & 2.567698 & & & \\
\hline Total & 921.9795 & 341 & & & & \\
\hline
\end{tabular}

Gambar 17. Nilai ANOVA untuk waktu yang digunakan saat menemukan judul berita lain dalam website Republika pada perangkat yang berbeda (monitor PC, tablet dan mobile phone)

[Sumber: Dokumentasi Penulis]

Gambar 17 menunjukan bahwa analisa signifikasi untuk monitor PC, tablet dan mobile phone adalah signifikan, hal ini terjadi karena nilai P-Value sebesar $(5,84 \mathrm{E}-$ $05)$ dan F Hitung $(10,03)$ lebih besar dari F Critical. 
3. Nilai sebaran nilai rata-rata untuk waktu yang digunakan dalam menemukan menu ekonomi pada monitor PC, tablet dan mobile phone adalah 8.42 untuk monitor, 7.67 untuk tablet dan 7.30 untuk mobile phone dengan sebaran jumlah data atau standar deviasi sebesar 1.44 untuk monitor, 1.57 untuk tablet dan 1.77 untuk mobile phone, seperti yang terlihat pada gambar 18 .

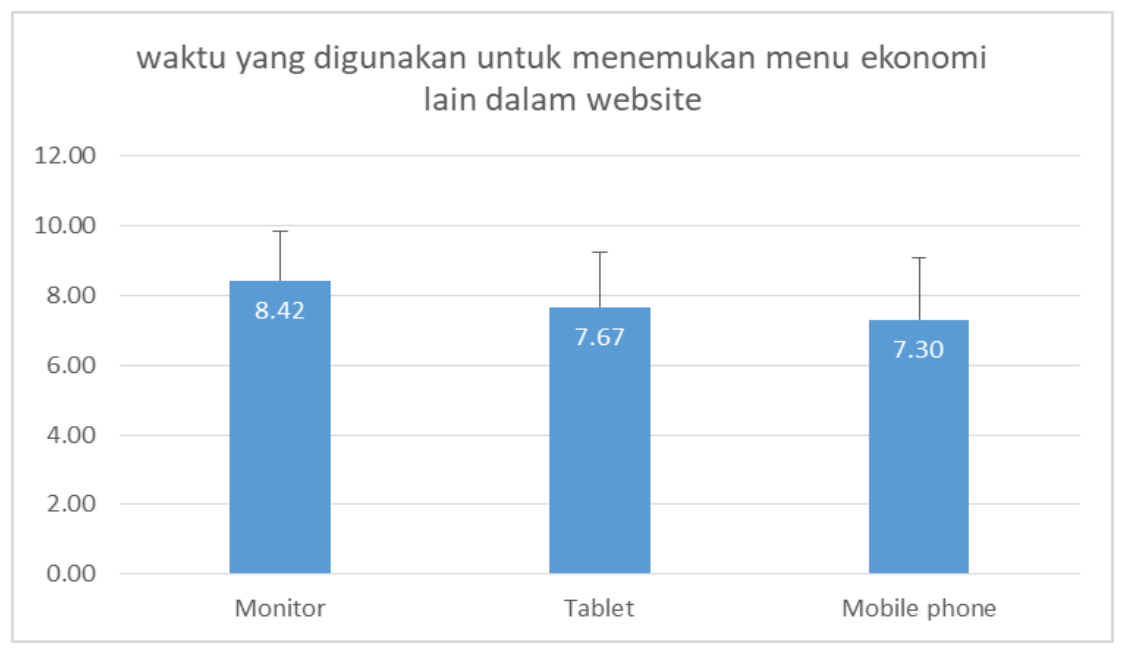

Gambar 18. Sebaran nilai rata-rata dan standar deviasi waktu yang digunakan untuk menemukan menu ekonomi dalam website Republika

[Sumber: Dokumentasi Penulis]

Data tersebut menunjukkan bahwa pengguna lebih cepat menemukan menu ekonomi dalam monitor PC dibandingkan dengan tablet dan mobile phone. Adapun nilai signifikansi dapat dilihat sebagai berikut:

Anova: Single Factor

SUMMARY

\begin{tabular}{lrrrl}
\hline \multicolumn{1}{c}{ Groups } & Count & \multicolumn{1}{c}{ Sum } & Average & Variance \\
\hline Monitor & 114 & 960 & 8.421053 & 2.086633 \\
Tablet & 115 & 882 & 7.669565 & 2.486346 \\
Mobile phone & 115 & 839 & 7.295652 & 3.174981 \\
\hline
\end{tabular}

\begin{tabular}{|c|c|c|c|c|c|c|}
\hline Source of Variation & $S S$ & $d f$ & $M S$ & $F$ & $P$-value & $F_{\text {crit }}$ \\
\hline Between Groups & 75.16515 & 2 & 37.58258 & 14.54373 & $8.68 \mathrm{E}-07$ & 3.022205 \\
\hline Within Groups & 881.1808 & 341 & 2.584108 & & & \\
\hline Total & 956.3459 & 343 & & & & \\
\hline
\end{tabular}

Gambar 19. Nilai ANOVA untuk waktu yang digunakan saat menemukan menu ekonomi dalam website Republika pada perangkat yang berbeda (monitor PC, tablet dan mobile phone)

[Sumber: Dokumentasi Penulis]

Gambar 19 menunjukan bahwa analisa signifikasi untuk monitor PC, tablet, dan mobile phone adalah signifikan karena nilai P-Value sebesar $(8,68 \mathrm{E}-07)$ dan $\mathrm{F}$ Hitung $(14,54)$ lebih besar dari F Critical. 


\subsection{Pembahasan}

Dalam penelitian ini dapat diidentifikasi beberapa hal terkait perubahan layout pada perangkat monitor PC, tablet, dan mobile phone terhadap pengguna.

1. Pada Kompas.com perangkat monitor PC memiliki nilai sebaran rata-rata yang lebih tinggi dibandingkan perangkat tablet dan mobile phone seperti yang terlihat pada tabel 1. Sebaran nilai lebih tinggi adalah monitor PC untuk setiap tugas yang diberikan kepada pengguna dalam mencari headline, berita lain dan menu ekonomi pada website.

Tabel 1. Sebaran nilai rata-rata kompas.com

\begin{tabular}{|l|c|c|c|}
\hline & Monitor & Tablet & $\begin{array}{c}\text { Mobile } \\
\text { phone }\end{array}$ \\
\hline $\begin{array}{l}\text { waktu yang digunakan untuk menemukan } \\
\text { judul headline dalam website }\end{array}$ & 8.31 & 7.93 & 7.50 \\
\hline $\begin{array}{l}\text { waktu yang digunakan untuk menemukan } \\
\text { judul berita lain dalam website }\end{array}$ & 8.30 & 7.69 & 7.36 \\
\hline $\begin{array}{l}\text { waktu yang digunakan untuk menemukan } \\
\text { menu ekonomi lain dalam website }\end{array}$ & 8.36 & 7.58 & 7.19 \\
\hline
\end{tabular}

Sedangkan nilai P-Value untuk setiap tugas yang diberikan kepada pengguna memiliki nilai kurang dari 0.05

Tabel 2. Nilai signifikasi kompas.com

\begin{tabular}{|l|c|}
\hline & P-Value \\
\hline $\begin{array}{l}\text { waktu yang digunakan untuk menemukan judul headline } \\
\text { dalam website }\end{array}$ & 0.00038 \\
\hline $\begin{array}{l}\text { waktu yang digunakan untuk menemukan judul berita lain } \\
\text { dalam website }\end{array}$ & $5.83 \mathrm{E}-05$ \\
\hline $\begin{array}{l}\text { waktu yang digunakan untuk menemukan menu ekonomi lain } \\
\text { dalam website }\end{array}$ & $8.68 \mathrm{E}-07$ \\
\hline
\end{tabular}

2. Pada jpnn.com perangkat monitor PC memiliki nilai sebaran rata-rata yang lebih tinggi dibandingkan perangkat tablet dan mobile phone seperti yang terlihat pada tabel 3. Sebaran nilai lebih tinggi adalah monitor PC untuk setiap tugas yang diberikan kepada pengguna dalam mencari headline, berita lain dan menu ekonomi pada website. 
Tabel 3. Sebaran nilai rata-rata jpnn.com

\begin{tabular}{|l|c|c|c|}
\hline & Monitor & Tablet & $\begin{array}{c}\text { Mobile } \\
\text { phone }\end{array}$ \\
\hline $\begin{array}{l}\text { waktu yang digunakan untuk menemukan } \\
\text { judul headline dalam website }\end{array}$ & 8.44 & 7.97 & 7.62 \\
\hline $\begin{array}{l}\text { waktu yang digunakan untuk menemukan } \\
\text { judul berita lain dalam website }\end{array}$ & 8.21 & 7.66 & 7.31 \\
\hline $\begin{array}{l}\text { waktu yang digunakan untuk menemukan } \\
\text { menu ekonomi lain dalam website }\end{array}$ & 8.45 & 7.85 & 7.54 \\
\hline
\end{tabular}

Sedangkan nilai P-Value untuk setiap tugas yang diberikan kepada pengguna memiliki nilai kurang dari 0.05

Tabel 4. Nilai signifikasi jpnn.com

\begin{tabular}{|l|c|}
\hline & P-Value \\
\hline $\begin{array}{l}\text { waktu yang digunakan untuk menemukan judul headline } \\
\text { dalam website }\end{array}$ & 0.00032 \\
\hline $\begin{array}{l}\text { waktu yang digunakan untuk menemukan judul berita lain } \\
\text { dalam website }\end{array}$ & 0.00052 \\
\hline $\begin{array}{l}\text { waktu yang digunakan untuk menemukan menu ekonomi lain } \\
\text { dalam website }\end{array}$ & 0.00025 \\
\hline
\end{tabular}

3. Pada Republika.co.id perangkat monitor PC memiliki nilai sebaran rata-rata yang lebih tinggi dibandingkan perangkat tablet dan mobile phone seperti yang terlihat pada tabel 5. Sebaran nilai lebih tinggi adalah monitor PC untuk setiap tugas yang diberikan kepada pengguna dalam mencari headline, berita lain dan menu ekonomi pada website.

Tabel 5. Sebaran nilai rata-rata republika.co.id

\begin{tabular}{|l|c|c|c|}
\hline & Monitor & Tablet & $\begin{array}{c}\text { Mobile } \\
\text { phone }\end{array}$ \\
\hline $\begin{array}{l}\text { waktu yang digunakan untuk menemukan } \\
\text { judul headline dalam website }\end{array}$ & 8.38 & 8.03 & 7.54 \\
\hline $\begin{array}{l}\text { waktu yang digunakan untuk menemukan } \\
\text { judul berita lain dalam website }\end{array}$ & 8.37 & 7.77 & 7.43 \\
\hline $\begin{array}{l}\text { waktu yang digunakan untuk menemukan } \\
\text { menu ekonomi lain dalam website }\end{array}$ & 8.42 & 7.67 & 7.30 \\
\hline
\end{tabular}

Sedangkan nilai P-Value untuk setiap tugas yang diberikan kepada pengguna memiliki nilai kurang dari 0.05 
Tabel 6. Nilai signifikasi republika.co.id

\begin{tabular}{|l|c|}
\hline $\begin{array}{l}\text { waktu yang digunakan untuk menemukan judul headline } \\
\text { dalam website }\end{array}$ & P-Value \\
\hline $\begin{array}{l}\text { waktu yang digunakan untuk menemukan judul berita lain } \\
\text { dalam website }\end{array}$ & $5.83 \mathrm{E}-05$ \\
\hline $\begin{array}{l}\text { waktu yang digunakan untuk menemukan menu ekonomi lain } \\
\text { dalam website }\end{array}$ & $8.68 \mathrm{E}-07$ \\
\hline
\end{tabular}

Apabila dilihat secara mendalam sebaran nilai rata-rata pada website Kompas, JPNN, dan Republika untuk setiap tugas yang diberikan tidak memiliki rentang yang terlalu jauh. Nilai P-value untuk setiap website juga berada dibawah 0.05.

\section{KESIMPULAN}

Dari hasil dan pembahasan yang ada menggunakan ANOVA, ditemukan bahwa perubahan layout pada website surat kabar dalam hal ini monitor PC, tablet, dan mobile phone secara signifikan mempengaruhi pengguna. Hasil tersebut tidak hanya ditemukan pada satu website namun pada ketiga website dalam hal ini website kompas: http://www.kompas.com/, website JPNN: https://www.jpnn.com/, dan website Republika: https://www.republika.co.id/. Adapun untuk nilai sebaran yang menunjukkan bahwa monitor memiliki nilai yang tinggi menunjukkan bahwa pengguna lebih familiar saat menggunakan perangkat monitor PC saat mengakses berita dari website dibandingkan dengan tablet dan mobile phone.

Dalam sebuah website responsif, tidak hanya layout yang harus dapat fleksibel mengikuti besar monitor. Arah kedepan untuk penelitian tentu dapat dikembangkan pada gambar dan media yang dalam sebuah website yang responsif harus dapat fleksibel dan mengikuti besar monitor.

\section{DAFTAR PUSTAKA}

Beaird, J. (2010). The Principles of Beautiful Web Design. (K. Steele, Ed.) (Second Edi). Canada: SitePoint Pty Ltd.

Elliot, B. Y., \& Stocks, J. A. Y. (2009). Sexy Web. (Kelly Steele, Ed.). Canada: SitePoint Pty. Ltd.

Elvinaro, A. (2015). Sejarah Surat Kabar di Indonesia. Retrieved July 12, 2018, from http://suakaonline.com/8920/2016/06/25/sejarah-surat-kabar-di-indonesia/

Galitz, W. O. (2007). The Essential Guide to An Introduction to GUI Design Principles and Techniques. (E. Robert, Ed.), Xtemp01 (Second Edi). Canada: Robert Ipsen.

Ihlström, C. (2005). The e-newspaper innovation: converging print and online. International Workshop on Innovation and Media: Managing Changes, Technologies, Products and Processes. $f$

Kiisa, K. (2015). From historical newspaper to e-newspaper . Challenge for libraries, 110. 
Marcotte, E. (2011). Responsive Web Design (Mandy Brow). New York: Jeffrey Zeldman. Mvungi, Joel ; Tossy, T. (2015). Usability Evaluation Methods and Principles for the Web. International Journal of Computer Science and Software Engineer (IJCSSE), 4(7), 165-171.

Nielsen, J. (1999). Differences Between Print Design and Web Design. Retrieved July 7, 2018, from https://www.nngroup.com/articles/usability-101-introduction-tousability/

Nielsen, J. (2012, January 4). Usability 101: Introduction to Usability. Retrieved July 7, 2018, from https://www.nngroup.com/articles/usability-101-introduction-tousability/

Veen, J. (2001). The Art \& Science of Web Design. United States of America: New Riders. 